\title{
Wlaściwości ludyczne opowiadań i bajek terapeutycznych (na wybranych przykładach)
}

Marta Bolinska 
NAPIS Seria XIV 2008

\author{
Marta Bolińska
}

\title{
Właściwości ludyczne opowiadań i bajek terapeutycznych (na wybranych przykładach)
}

Donoć już Szeherezada opowiadała historie, by wyleczyć sultana z depresji. WyPą̧tkowa moc lektury została doceniona również przez starożytnych. Otóż przed wejściem do biblioteki aleksandryjskiej widniał napis: „Lekarstwo na umysł”. Pod koniec XIII wieku w Kairze w ramach terapii szpitalnej czytano Koran, a w Europie już od XVIII wieku czytanie i słuchanie pobożnych tekstów wykorzystywano jako formę leczenia psychicznie chorych ${ }^{1}$. Także i dziś lektura nie traci na wartości, jednak niekiedy zostaje zdominowana (choć nie wyparta) przez inne środki oddziaływania.

Jak pisze Katarzyna Szeliga:

Obecnie obserwujemy intensywny wzrost zainteresowania tą formą działań terapeutycznych. Coraz większą popularnością cieszą się pozycje z zakresu lub pogranicza biblioterapii. Dla przykładu można wymienić zarówno publikacje autobiograficzne, beletrystyczne, jak też literaturę fachową i poradniki opracowane przez fachowców zajmujących się tą dziedziną².

Najwdzięczniejszym odbiorcą tej formy kontaktu z lekturą wydaje się dziecko. Ono umie cieszyć się i bawić słowem, a także opowieścią.

W świecie dzieci, obok czynności czytania i słuchania, również opowiadanie i tworzenie, czyli wymyślanie wlasnych historii jest czynnikiem wpływającym na rozwój

${ }^{1}$ Zob. W. Szulc, Sztuka w stużbie medycyny. Od Antyku do Postmodernizmu, Poznań 2001.

${ }^{2}$ K. Szeliga, Historia Guziolka, czyli jak tworzyć i wykorzystywać bajki i opowiadania w biblioterapii oraz rozwoju aktyuności twórczej dziecka w' wieku przedszkolnym, Kraków 2005, s. 11. 
społeczno-emocjonalny. Bo dzieci „oprócz rysowania, oglądania ilustracji i obrazów pragną też słuchać opowieści”'. Jest to o tyle ważne, że

potrzeba słuchania opowieści - podaje Alicja Baluch — jest jedną z podstawowych potrzeb dzieci. Dlatego tak chętnie słuchają one fabul, charakterystycznych dla prostych form literatury. Te proste formy to podania i legendy; także gatunki bardziej skomplikowane, baśnie, są lubiane i chętnie przyjmowane przez zastuchane dzieci. Dzieci w sposób naturalny są otwarte na poznanie przekazywane poprzez fabuły — ustnie ${ }^{4}$.

Stąd nie tylko czytanie, ale zwłaszcza opowiadanie, i to historii także tworzonych przez siebie, stanowi dla nich wartość podstawową. Bywa najlepszą zabawą i miłą rozrywką. Ponadto już samo słuchanie czy przełożenie słów na obrazy wyobrażeniowe wymaga kreatywnego zaangażowania odbiorcy. Snucie zaś opowiastek samo w sobie jest aktywnością twórczą̧

Tym bardziej, że - jak pisze Jerzy Cieślikowski przy okazji uzasadniania tytułu swojej książki Wielka zabawa..., poświęconej folklorowi i wyobraźni dziecka:

Wszystko, co dzieci wzięły od dorosłych, co dla nich dorośli stworzyli, co same wymyśliły i wreszcie co dorośli dla nich napisali najlepszego, służy przede wszystkim i w pierwszym rzędzie zabawie. To jest wielkie hasło i emblemat, pod którym dziecko bawi się, a więc tworzy, reprodukuje, upaja się i igra słowem. Zresztą [...] tekst słowny pozostaje dla dziecka przedmiotem różnorodnych eksperymentów - recytacji, śpiewu, tańca, teatralizacji6.

\section{Zabawa i terapia}

W kontakcie z dzieckiem ${ }^{7}, \mathrm{z}$ różnych powodów i w rozmaitych okolicznościach, dorośli wykorzystują kołysanki, wyliczanki, wiersze i wierszyki, klechdy i inne opowieści prozą oraz bajeczki z morałem i bez niego, bajki czy baśnie.

Nie wszystkie działania mają formę stricte terapeutyczną. Wiele z nich ma przede wszystkim charakter edukacyjny i wychowawczy oraz rozwojowy; wpływa na kształto-

3 A. Baluch, O królewnie odbitej $w$ zwierciadle natury, w: eadem, Archetypy literatury dziecięcej, Wroclaw 1993 , s. 34.

${ }^{4}$ Eadem, Od prostych form do arcydzieła, w: ibidem, s. 69.

${ }^{5}$ Zob. D. Kubicka, Twórcze działanie dziecka w sytuacji zabawowo-zadaniowej, Kraków 2003.

${ }^{6} \mathrm{~J}$. Cieślikowski, Wielka zabawa. Folklor dziecięcy, uyobraźnia dziecka, wiersze dla dzieci, Wrocław 1967, s. 7.

7 Zob. A. Baluch, Książka jest światem. O literaturze dla dzieci małych oraz dla dzieci starszych i nastolatków, Kraków 2005. 
wanie postaw, zachowań i emocji odbiorców; pomaga zrozumieć siebie i świat. Często drogą do celu bywa zabawa, również zabawa w opowiadanie.

Najpierw, w dużym skrócie, uporządkujemy najważniejsze pojęcia (arteterapia, biblioterapia, bajkoterapia oraz baśń, bajka i opowiadanie).

Przez a r t e te r a p i ę ${ }^{8}$ należy rozumieć wykorzystywanie twórczości w celach leczniczych (np. gra na instrumentach, taniec, lektura książek, rysowanie ${ }^{9}$ ). Jedną z najdawniejszych jej form jest terapia czytelnicza, zwana bibli o te r a pi ą ${ }^{10}$, przez którą rozumie się używanie lub stosowanie wyselekcjonowanych materiałów czytelniczych jako pomocy terapeutycznej w medycynie i psychiatrii oraz poradnictwo w rozwiązywaniu problemów osobistych poprzez ukierunkowane czytanie ${ }^{11}$.

Wielu badaczy sądzi, że bajka i opowiadanie mogą się dobrze sprawdzić jako element biblioterapii, zwłaszcza wśród dzieci w wieku przedszkolnym, choć i starsi odbiorcy, również dorośli, mogą tu znaleźć coś dla siebie ${ }^{12}$. Należy jednak odróżnić biblioterapię kliniczną, której celem jest leczenie zaburzeń w zachowaniach ludzi chorych, od biblioterapii wychowawczej, która dotyczy ekspresji, twórczości i rozumienia innych. Nas interesuje to drugie ujęcie. Jego celem, jak pisze Katarzyna Szeliga, jest skorygowanie postaw, kompensacja i samorealizacja, samopoznanie, wreszcie osiągnięcie dojrzałości emocjonalnej ${ }^{13}$. Literatura w tym przypadku traktowana jest nie tyle jako środek leczniczy, co jako forma komunikacji, porozumienia. Korzyści, jakie płyną z wykorzystywania bajek i opowiadań w pracy wychowawczo-dydaktycznej ${ }^{14}$, należą do sfery intelektualnej, społecznej, emocjonalnej. Zresztą zarówno słuchanie, jak i tworzenie opowieści może wplywać na rozwój osobowości dziecka i dorosłego.

Uważa się, że baśnie, bajki i zabawy przyczyniają się między innymi do redukcji lęku u dzieci, pozwalają odreagowywać napięcia, umożliwiają poznawanie wzorów modeli zachowań czy wreszcie pomagają wyzwalać spontaniczność. W bajkoter a p i i można wyróżnić trzy podstawowe rodzaje utworów (bajek terapeutycznych): bajkę relaksacyjną, której podstawowym zadaniem jest uspokojenie dziecka, zwłaszcza

8 Por. W. Szulc, Kulturoterapia - uykorzystanie sztuki i działalnośi kulturalno-oświatowej w lecznictuie, Poznań 1994; E. J. Konieczna, Arteterapia w teorii i praktyce, Kraków 2004.

${ }^{9}$ Zob. G. D. Oster, P. Gould, Rysunek w psychoterapii, tt. A. i M. Kocmajor, Gdańsk 2005.

${ }^{10}$ Zob. W. Szulc, Biblioterapia. Stan badań, „Biuletyn Głównej Biblioteki Lekarskiej” 1991, nr 345.

11 Zob. M. Molicka, Bajki terapeutyczne dla dzieci, Poznań 2000; I. Osuchowska, Wykorzystanie bajek i baśni u" psychoterapii dzieci i młodzieży, w: Baśń i dziecko, red. H. Skrobiszewska, Warszawa 1978.

${ }_{12}$ Zob. I. Borecka, Biblioterapeuta w poszukiwaniu tożsamości zauodowej, Wrocław 1997; Dziecko w zabawie i śuiecie języka, red. A. Brzezińska, T. Czuba, G. Lutomski, B. Smykowski, Poznań 1995; A. Lazarus, Wyobraźnia w psychoterapii, Gdańsk 2000.

${ }^{13}$ Zob. K. Szeliga, Historia Guziolka..., op. cit., s. 13.

${ }^{14}$ Zob. H. Wrona-Polańska, Zdrowie jako funkcja twórczego radzenia sobie ze stresem. Psychologiczne mechanizmy i wwarunkowania zdrouria $w$ zawodzie nauczyciela, Kraków 2003; A. Włodarczyk, Styl terapeutyczny w pracy nauczyciela polonisty, Kraków 2007. 
poprzez wizualizację, dalej bajkę psychoedukacyjną (wprowadzenie zmian w zachowaniu dziecka) oraz bajkę psychoterapeutyczną, której cel stanowi redukcja lęków, powstałych czy to w wyniku negatywnego doświadczenia (tzw. lęk odtwórczy), czy też w wyniku niewłaściwej stymulacji wyobraźni (tzw. lęk wytwórczy) oraz niezaspokojonych potrzeb.

W literaturze przedmiotu spotyka się także ujęcie łączące elementy charakterystyczne dla poszczególnych typów bajek, wskutek czego wyodrębnia się też bajkę relaksacyjno-terapeutyczną. Generalnie utwory tego rodzaju powinny uspokajać, redukować problemy emocjonalne, wspierać słuchaczy i czytelników, zwłaszcza młodych, we właściwym rozwoju osobowości. Oczywiście, bajki oparte na założeniach psychoanalizy będą różniły się od tych korzystających z założeń koncepcji poznawczo-behawioralnej, odmienne będą również sposoby ich oddziaływania.

\section{Bajka terapeutyczna i jej cechy swoiste}

W odniesieniu do opowiadań tworzonych dla dzieci w celach terapeutycznych przyjęto pojęcie bajki terapeutycznej ${ }^{15}$. Bajka terapeutyczna, podobnie jak baśń, najlepiej trafia do dzieci w wieku od 4 do 9 lat, do nich także jest przede wszystkim skierowana. Zasadnicze różnice między baśnią a bajką wynikają z ich przynależności gatunkowej. Otóż w potocznym rozumieniu nazw „bajka” i „baśń” używa się zamiennie na oznaczenie utworów docierających do dzieci czy przez nie lubianych, w których pierwiastek fantastyczny odgrywa niepoślednią rolę. Jednak w literackiej genologii funkcjonują one jako formy odrębne. Zasadnicza różnica sprowadza się do tego, że bajka rozumiana jest jako zazwyczaj krótki i dowcipny utwór, najczęściej pisany wierszem, przede wszystkim o charakterze dydaktycznym, także satyrycznym. Baśń natomiast postrzegana bywa jako utwór narracyjny, często zakorzeniony w tradycji ustnej i w folklorze, mający pewne walory tudzież funkcje ludyczne, poznawcze, kompensacyjne. Opowiadania terapeutyczne traktowane są jako historie z życia wzięte, często ujmowane w strukturę wspomnienia. Zadaniem zaś bajek terapeutycznych jest uczenie, głównie odpowiednich zachowań.

Katarzyna Krasoń wymienia kryteria, wedle których powinna być skonstruowana bajka terapeutyczna. Tego typu utwory mają bowiem określoną strukturę, w ramach której najważniejsze elementy to: odpowiednia konstrukcja, bohater (transformujący, archetyp, translator) $\mathrm{i}$ intryga ${ }^{16}$.

${ }^{15}$ Zob. M. Molicka, Bajkoterapia. O lękach dzieci i nowej metodzie terapii, Poznań 2002, s. 153-217.

${ }^{16}$ Zob. K. Krasoń, Baśniowe odkrywanie znaczeń jako wspomaganie rozwoju dziecka, w: Kultura literacka dzieci i młodzieży u progu XXI stulecia, red. J. Papuzińska, G. Leszczyński, Warszawa 2002; eadem, Obrazkowe oswajanie świata, „Guliwer” 1999, nr 5. 


\section{Według Brunona Bettelheima:}

Jeśli opowieść ma naprawdę przykuć uwagę dziecka, musi je zabawić i obudzić w nim ciekawość. Jeśli jednak ma wzbogacić jego życie, musi pobudzać jego wyobraźnię, pomóc dziecku w rozwijaniu inteligencji i porządkowaniu uczuć, musi mieć związek z jego lękami i dążeniami oraz umożliwić mu pełne rozeznanie własnych trudności, a zarazem podać sposoby rozwiązywania nękających je problemów. Krótko mówiąc, musi się odnosić jednocześnie do wszystkich aspektów dziecięcej osobowości i niczego przy tym nie bagatelizować ${ }^{17}$.

Toteż ważną inspiracją do opracowania bajek psychoterapeutycznych

były baśnie, których analiza pod kątem zastosowanych mechanizmów psychologicznych przyczyniła się do możliwości skonstruowania utworów podobnych, uzupelnionych o dodatkowe techniki terapeutyczne ${ }^{18}$.

W zestawieniu z bajkami relaksacyjnymi czy edukacyjnymi, typowe bajki terapeutyczne mogą być obszerniejsze, mieć bardziej rozbudowaną fabulę, bowiem w związku z rozgrywającymi się zdarzeniami można uwzględnić w nich założenia teoretyczne dotyczące struktury konstrukcyjnej, równocześnie zaś ułatwić wystąpienie mechanizmu naśladownictwa i identyfikacji oraz przewarunkowania. Opowiadania i bajki psychoterapeutyczne, podobnie jak psychoedukacyjne, pokazują inny sposób myślenia i przez to odczuwania sytuacji lękotwórczej ${ }^{19}$.

Jak pisze Maria Molicka:

Bajka psychoterapeutyczna zawiera niektóre elementy baśni (kompensacja potrzeb) i bajki psychoedukacyjnej (wzory), uzupełnione o dawanie wsparcia, co w efekcie ma poprzez mechanizmy psychologiczne (identyfikację z bohaterem, odwrażliwienie i wiedzę) zbudować zasoby osobiste, a tym samym spowodować redukcję napięcia. Nabycie zasobów osobistych powoduje przyjęcie „za swoje” nowych strategii i ukierunkowuje na realistyczną samorealizację ${ }^{20}$.

Wartym odnotowania zbiorem bajek terapeutycznych jest książka Katarzyny Szeligi - Historia Guziolka... ${ }^{21}$

${ }_{17}$ B. Bettelheim, Cudowne i pożyteczne. O znaczeniach i wartościach baśni, t. 1-2, tt. D. Danek, Warszawa 1985, s. 41-42.

${ }^{18}$ M. Molicka, Bajkoterapia..., op. cit., s. 170.

19 Zob. ibidem.

${ }^{20}$ Ibidem.

21 Zob. K. Szeliga, Historia Guziolka..., op. cit. 


\section{Wartości ludyczne gier i zabaw}

Słownikowe ludus oznacza zabawę, rozrywkę, widowisko, wreszcie - sztukę teatralną. Specyficznie pojmowanych gier i zabaw dotyczą także opowiadania edukacyjne, relaksacyjne i terapeutyczne, które mogą sprzyjać specjalnie pojmowanej odmianie widowiska, jakim może stać się głosowy teatr w opowieści.

Badacze przy tym rozróżniają pojęcia: „gra” i „zabawa”. Za literaturą przedmiotu Jerzy Cieślikowski gry traktuje jako zabawy skonwencjonalizowane i opowiada się za podziałem Fryderyka Queyrata, który dzieli je na: dziedziczne, naśladowcze oraz oparte na wyobraźni, natomiast zabawy pojmuje jako przedmiot swobodnej inwencji dziecka ${ }^{22}$. Włącza je również do szeroko rozumianego dziecięcego folkloru, w którym umieszcza także teksty gier, dziecięce rymy, igraszki i powiedzenia oraz wszelkie twory dziecięcej pomysłowości i wyobraźni, które powstały i powstają dalej niezależnie od środowiska wsi, były i są wspólne wszystkim dzieciom jako psychofizyczne kategorie człowieka ${ }^{23}$.

Queyrat uważa, że cechą zabaw jest instynkt i że wszędzie ważną rolę odgrywa wyobraźnia. Sądzi ponadto, że nawet odtwórcze zabawy nie są wierną kopią rzeczywistości. Jako dziedziczne traktuje na przykład zabawy w wojnę czy upodobanie płci męskiej do gier hazardowych. Przypuszcza również, że nawet w zabawach naśladowczych odkryć można pierwiastek dziedziczności, bowiem mogą one stać się formą przygotowania do życia. Bywa, że zabawa naśladowcza się przeżywa (np. strzelanie z procy), zatem zabawa pierwotnie naśladowcza staje się już tylko dziedziczna.

Oprócz podziału historycznego, Cieślikowski w studium Wielka zabawa... proponuje zwrócić uwagę na klasyfikację gier ze względów wychowawczych (wtedy uwzględnia się element kształtujący w dziecku cechy przyszłego dorosłego). I tak, za Konradem Lange, dzieli gry na: ruchowe, kształcące zmysły, artystyczne oraz sprzyjające rozwojowi inteligencji. Powolując się na innych badaczy, podaje podział zabaw na te, które sprzyjają rozwojowi myślenia abstrakcyjnego (wykształcanie umiejętności rozumowania), dalej na takie, które przyczyniają się do utrwalania samowiedzy oraz na ćwiczenia pomocne w odtwarzaniu wrażeń ${ }^{24}$ i pojęć. Za Karolem Groosem ujmuje zabawy jako rozwijające zmysły (dotyku, wzroku, słuchu), następnie wymienia zabawy ruchu oraz kształcące wyższe zdolności duchowe. Kolejno, uwzględniając wcześniejsze prace ${ }^{25}$, Jerzy Cieślikowski dzieli zabawy na: wyuczone (zbiorowe), kształcące pier-

\footnotetext{
22 Zob. J. Cieślikowski, Wielka zabawa..., op. cit., s. 9, 185; F. Queyrat, Gry i zabawy dziecięce. Studium nad wyobraźnia dzieci, tł. M. Rodysowa, Warszawa 1905, s. 79.

${ }^{23}$ Zob. J. Cieślikowski, Wielka zabawa..., op. cit., s. 6 i nast.

${ }^{24}$ Zob. W. Sikorski, Wychowanie fizyczne, w: Encyklopedia wychowawcza, t. 2, cz. 1, Warszawa b.r., s. 1013-1014.

${ }^{25}$ Zob. J. Cieślikowski, Wielka zabawa..., op. cit.
} 
wiastki o charakterze społecznym, na zabawy swobodne (przeważnie fizyczne) oraz na zabawy-zajęcia, w których dominuje pierwiastek intelektualny (spostrzegawczość i wytwórczość), odróżnia zabawy przygotowawcze (wyładowujące siły) od zabaw naśladowczych.

Wreszcie, idąc śladem Gérard-Vareta, wyodrębnia zabawy, których założeniem jest czyn (walka) i zabawy, których podstawą jest urojenie.

$\mathrm{U}$ podstaw naszych zainteresowań leżą zabawy-gry, rozgrywane według z góry określonych i przeważnie niezmiennych regul, które mają charakter wyuczony (zbiorowy) oraz zabawy i zajęcia, które sprzyjają kreatywności. Ważne są tu także wyobraźnia i instynkt, rozwój inteligencji, utrwalanie samowiedzy i umiejętność odtwarzania wrażeń, rozwijanie zmysłów i kształcenie wyższych zdolności duchowych, przygotowanie do efektywnego spożytkowania sił fizycznych oraz osiaganie celu poprzez działanie.

Zgodnie z teoriami zabawy przyjęło się uważaććc $c^{26}$ ze zabawa jest pierwotniejsza od kultury. Stąd Johan Huizinga ${ }^{27}$ zajmuje się nie miejscem zabawy pośród innych zjawisk kultury, ale tym, w jak dużym stopniu sama kultura ma charakter zabawy. Według niego zabawa względem kultury ma charakter pierwotny, jako obiektywnie spostrzegana, konkretnie określona czynność, podczas gdy kultura jest już tylko formą zabawy, jej wyrazem. Inni badacze uważają wręcz, że byt wynika z zabawy, bowiem kultura zaczyna się jako zabawa, lecz powstaje nie z zabawy, ale w zabawie. Bajkoterapia jest w pewnym sensie zabawą i równocześnie nią nie jest.

Cieślikowski podkreśla, że zabawa pozostaje również poza sferą materialnych korzyści, jest więc działalnością, która przebiega wewnątrz pewnych granic określonych przez czas i przestrzeń według przyjętego porządku i dobrowolnie określonych reguł. Dlatego nastrojem zabawy jest zachwyt (święto, uczucie uniesienia lub wyniesienia, napięcie, wesołość, odprężenie). Akt bawienia się jest także świadomym wyjściem z życia oficjalnego w tymczasową sferę aktywności; uwolnienia od krytycznych form zachowania czy postępowania.

Wreszcie zabawa ma cel sama w sobie, zaś jej świat stanowi projekcję świata rzeczywistego, jego przedmiotów i stosunków. Czynności związane z zabawą są domeną tzw. osobowości wtórnej (chwilowej, kreującej siebie, potrzebnej do przyjęcia zabawy, do odegrania zabawowej roli), która stanowi część wydzieloną osobowości stałej i jest przez nią obserwowana. Zabawa prawdziwa wymaga wytworzenia osobowości wtórnej, zaproszenia wyobraźni i wzruszenia.

Można bawić się indywidualnie lub zbiorowo. Niemniej wejście w rolę nie ma dla dziecka nic z parodiowania, jest utożsamianiem się na serio. Ta swoista teatralizacja wła-

26 Zob. ibidem, s. 186.

${ }^{27}$ Zob. J. Huizinga, Homo ludens. Zabawa jako źródło kultury, tł. M. Kurecka, W. Wirpsza, Warszawa 1968. 
ściwie nie jest teatralizacją, ponieważ całkowite wejście w rolę nie jest przeznaczone dla kogoś z zewnątrz, tylko dla siebie samego. To wyjątkowa forma zjednoczenia się z rolą.

\section{Między zabawą a literaturą}

I oto właśnie, kiedy do dziecięcego świata wkracza fantastyka i to związana już z literaturą, pojawia się też potrzeba stykania się z formą, która odpowiadałaby dziecięcym wymaganiom. Potrzebna jest bajka. Z pewnym jednak zastrzeżeniem. Otóż

wydzielamy z bajki, rozumianej dość ogólnie, podgatunek nazwany b a je c z ką. I w ramach tak nieszczelnego pojęcia rozumiemy przez bajeczkę zbiór następujących dystynkcji: krótkość, magiczność, bohaterowie i substraty świata prezentowane na sposób epicki, estetyzacja języka ${ }^{28}$.

Zatem tworzenie za pomocą słowa świata odpowiadającego potrzebom dziecka niesie ze sobą pewne zobowiązania i konsekwencje. Stąd również narratorem bajki nie może być ka ż dy, „ale tylko ktoś znaczący, wyróżniony okolicznościami narracji”29. Właśnie wykorzystanie narracji w celu wpływania na wychowanie dziecka znajduje się w polu zainteresowań biblioterapii.

Budowanie nastroju, stwarzanie napięcia wewnątrz tekstu, kreowanie literackiego obrazu w bajkowo-baśniowym klimacie, kiedy na przykład tajemniczy głos dobrze znanej osoby zapowiada ciekawą opowieść, odbywa się przede wszystkim na plaszczyźnie języka, bo za pomocą słów następuje „stwarzanie świata”. Słowo zaczyna nabierać mocy sprawczej ${ }^{30}$, przeradza się w szczególny rodzaj baśniowego zaklęcia, które właściwie użyte, dzięki swojej sile, może zmienić życie bohaterów. Poruszanie się na granicy prawdy i zmyślenia, jawy i snu, posługiwanie się kontrastem, półcieniem, gradacją, powtórzeniem, sprzyja klimatowi tajemniczości, tak ważnemu w opowieściach, zwłaszcza dla najmłodszych. Opowiadanie historii może odbywać się w domu i przedszkolu, wieczorem i przed południem, dla pojedynczego słuchacza lub grupy osób. W każdej jednak z tych sytuacji oczekiwane efekty - terapeutyczne czy też relaksacyjne lub edukacyjne z ludycznym akcentem - można osiągnąć, wykorzystując choćby walory ludzkiego głosu. Z tym, że zarówno nadawca, jak i odbiorca muszą poznać, przyjąć

\footnotetext{
28 J. Cieślikowski, Sposoby istnienia bajki dziecięcej, w: idem, Literatura i podkultura dziecięca, Wrocław 1975, s. 207.

${ }^{29}$ Idem, Baśn synkretyczna, w: ibidem, s. 71.

${ }^{30}$ Por. A. Baluch, Odkrywanie świata przedstawionego $w$ literaturze (O regułach czytania prozy narracyjnej przez dziecko), w: eadem, Dziecko i świat przedstawiony, czyli tajemnice dziecięcej lektury, Wroclaw 1994, s. 27; E. Balcerzan, Kregi wtajemniczenia: czytelnik, badacz, thumacz, pisarz, Kraków 1982; idem, Przez znaki. Granice autonomii sztuki poetyckiej. Na materiale polskiej poezji wspótczesnej, Poznań 1972, s. 35-39 (autor terminów „obserwator” i „uczestnik”).
} 
i respektować reguły gry, która się zawiązuje. Można więc przyjąć, że literacka kultura dzieci wywodzi się w dużej mierze z zabawy, nawet - zaczyna się w zabawie. Tym bardziej, że pozostaje poza sferą korzyści materialnych (bardziej kładzie nacisk na odprężenie, wiedzę, umiejętności lub spożytkowanie nadmiaru siły), dalej — jako forma działalności twórczej lub odtwórczej — przebiega w ramach granic określonych przez miejsce i czas oraz według umownie przyjętego porządku potrzeb. Wśród emocji dominuje radość, uniesienie, odprężenie. Zatem zabawa w czytanie, opowiadanie czy wymyślanie historii staje się $\mathrm{w}$ efekcie świadomym wyjściem z życia oficjalnego, wreszcie - ma cel sama w sobie, bowiem jest wejściem w określoną, wybraną rolę dla siebie samego. Utwory terapeutyczne, i to zarówno słuchane przez dzieci lub opowiadane im, jak też przez nie tworzone, wykazują zbieżność z założeniami zabawy wskazanymi przez Rogera Caillois, wedle którego akt zabawy jest dobrowolny, wyodrębniony, ujęty w normy, fikcyjny i ma niematerialną wartośćc ${ }^{31}$.

Jak pisze Jerzy Cieślikowski:

Jest to zabawa, w czasie której opowiadacz w przytomności słuchacza zmienia głos, stylistykę, leksykę. Podobnie jak to robi, oddając głos niby bohaterowi, gdy w rzeczywistości mówi za niego, odgrywa go ${ }^{32}$.

Jest to ważne, zwłaszcza wobec faktu, że bajka dziecięca z założenia jest konstrukcją narracyjną nastawioną na głośne czytanie — mówienie:

Więc konstrukcją z narratorem uobecnionym, zawsze tym samym i zawsze tylko jednym. Ale z prawem, i nie tylko z prawem, ale $z$ obowiązkiem — „udawania”, podkładania się pod innych, z prawem do mimikry ${ }^{33}$ -

zaznacza uczony. Dodaje także, iż opowiadacz glośny jest kimś,

kto się znajduje między komunikatem jako oznacznikiem a adresatem słuchaczem. Sam zaś komunikat — tekst drukowany — jest pomyślany z nastawieniem na głośne czytanie, zakładające, że jego optymalna jasność, przystępność i doskonałość są osiągalne przy jakiejś średniej umiejętności dramatycznej waloryzacji głosowej czytającego ${ }^{34}$.

Tworzony jest $\mathrm{w}$ ten sposób rodzaj teatru ${ }^{33}$, w którym istotne staje się przede wszystkim: zagranie głosem (dostosowanie siły głosu i modulacji do charakteru po-

${ }^{31}$ Zob. R. Caillois, Gry i ludzie, tł. A. Tatarkiewicz, M. Żukowska, Warszawa 2001, s. 71.

32 J. Cieślikowski, Baśń synkretyczna, op. cit., s. 52.

33 Ibidem.

${ }^{34}$ Ibidem.

35 Zob. Teatr jako zabawa i gra, w: Stownik wiedzy o teatrze, red. D. Kosiński i in., Bielsko-Biała 2007, s. 20-21. 
szczególnych segmentów opowieści - np. mówienie podniosłe, radosne, smutne, melancholijne, informacyjne), tempo mówienia, gest foniczny, postawa, skuteczny kontakt (w tym także wzrokowy) z odbiorcą i czynny proces komunikacji, wykorzystanie technik aktywnego słuchania (zwłaszcza dostrojenie, potwierdzanie i ujawnianie emocji). Sprzyja temu z pewnością wcielanie się w odpowiednie role oraz tworzenie więzi między opowiadaczem (jako pośrednikiem) a zaprojektowanym odbiorcą dzieckiem lub nawet dorosłym w czasie głośnej lektury. Najważniejsza sprawa wreszcie to osiągnięcie zaplanowanego celu — wywołanie zaciekawienia, zasłuchania, reakcji objawowej w postaci śmiechu, płaczu, ruchu ciała, jednym słowem: wywołanie przeżycia estetycznego.

Przed dzieckiem, czyli odbiorcą, dla którego w intencji nadawcy przeznaczone są utwory operujące kategorią fantastyki baśniowo-bajkowej, otwiera się świat, który - pisze Alicja Baluch —

opowiadany (czytany) przez pośrednika staje się poniekąd jego własnością. Bo im młodszy odbiorca, tym mocniej łączy osobę empirycznego "opowiadacza” z nie uświadomioną jeszcze funkcją wewnątrztekstową narratora. Stąd świat przedstawiony, jakikolwiek by on był, w oczach dziecka otrzymuje znamię realności, a ono samo czuje się jego bezpośrednim uczestnikiem ${ }^{36}$.

Zabawa zyskuje wartość realistycznej mocy, którą wykorzystać można w rzeczywistych sytuacjach codziennego życia, gdy trzeba radzić sobie z rozmaitymi trudnymi sytuacjami. A te bywają nieprzewidywalne.

Celem bajki relaksacyjnej jest wywołanie odprężenia i uspokojenie. Dlatego ta forma sięga zwłaszcza do wizualizacji. Zabawa w wymyślanie obrazów, uruchamianie wyobraźni, wspomagana na przykład muzyką (muzykoterapia) powoduje wywoływanie określonych stanów emocjonalnych i poprzez obrazowanie wewnętrzne powinna prowadzić do oczyszczenia i uwolnienia od napięć.

Bajka taka ma określony schemat oraz zespół rekwizytów-znaków (motywów). Otóź jej bohater przebywa w miejscu, które zna i w którym czuje się bezpiecznie, dlatego może spokojnie odpoczywać. Fabuła nie powinna być dynamiczna, ale za to wyróżniać się charakterystycznymi zdarzeniami, np. latanie, picie wody ze źródła, kąpiel pod wodospadem lub w deszczu ${ }^{37}$. Opowieść powinna trwać 3-7 minut. Zbyt długa może nie być efektywna. Konieczne jest także aktywizowanie sensoryczne, w tym uru-

\footnotetext{
${ }^{36}$ A. Baluch, Nauka lektury, w: eadem, Dziecko i świat przedstawiony..., op. cit., s. 62.

37 Zob. E. Małkiewicz, Bajki relaksacyjno-terapentyczne u' pracy z dziećmi z problemami emocjonalnymi, w: Wspomaganie rozu'oju, red. B. Kaja, Bydgoszcz 1997, s. 273; A. Lazarus, Wyobraźnia w psychoterapii, Gdańsk 2000, s. 11, 108.
} 
chamianie kanału wzrokowego, słuchowego i czuciowego. Ważnym czynnikiem jest także odpowiednie wprowadzenie w klimat opowieści, zapowiedź, że zaraz rozpocznie się bajka, oraz umiejętność wyciszenia się i zmniejszenie napięcia mięśniowego u opowiadacza i słuchaczy. Jak podaje Molicka:

im relaks głębszy, tym łatwiej o uspokojenie, odprężenie i lepsze samopoczucie. Zmartwienia, lęki, usuwają się na dalszy plan, wewnętrznie spokojni szybciej uporamy się z trudnościami. Przed opowiadaniem bajki osoba opowiadająca wprowadza dzieci w stan rozluźnienia, mówiąc: teraz posłuchamy bajeczki, usiądź wygodnie, jeszcze wygodniej, posłuchaj swego oddechu, możesz przymknąć oczy, wszystkie dźwięki oddalają się. Osoba opowiadająca bajkę relaksacyjną sama musi być odprężona, nie może odczuwać napięcia. Musi wyrównać swój oddech i rytmicznie, cichym głosem podawać tekst ${ }^{38}$.

Takie wspólne podążanie za bohaterami i opowieścią daje nie tylko poczucie wspólnoty, ale przede wszystkim dużo radości. Zabawa w relaks staje się jednocześnie prawdziwym odpoczynkiem, czyli poprzez czynnik ludus może zostać osiągnięty wyjątkowy efekt: movere, docere i delectare.

W bajkach psychoedukacyjnych nacisk położony jest na kognitywny sposób oddzialywania. Doświadczenia poznawcze z nich wynoszone dotyczą świata emocji dziecka, to jest ksztaltowania umiejętności rozpoznawania, nazywania i kontrolowania emocji. Molicka podkreśla, że zazwyczaj bohater bajki edukacyjnej

ma problem podobny do tego, który przeżywa dziecko; zdobywa ono doświadczenie poprzez świat bajkowy, gdzie uczy się, jakie wzory zachowania należy zastosować, rozszerza swoją samoświadomość, co sprzyja uczeniu się zachowania w sytuacji trudnej ${ }^{39}$.

Bajki takie, rozwijając inteligencję emocjonalną, powinny jednocześnie uczyć efektywnych strategii radzenia sobie, nie narzucając jednak zachowania. Powinny być propozycją, a nie gotową matrycą. Wśród charakterystycznych środków stosowane są tu znane dziecku metafory i symbole. Przybierają najczęściej postać krótkich historyjek.

Ich wesoły, optymistyczny, ale nie prześmiewczy charakter, powinien sprzyjać włączaniu świadomości emocjonalnej; w żadnym razie nie może być mowy o narzucaniu rozwiązań, bo to raczej zniechęca do naśladownictwa, budzi sprzeciw, wywołuje oburzenie, przez co oddala od właściwego celu - włączania wiedzy

\footnotetext{
${ }^{38}$ M. Molicka, Bajkoterapia..., op. cit., s. 155-156.

${ }^{39}$ Ibidem, s. 161.
} 
do emocji. Bajek tego typu może powstać nieskończenie wiele, bowiem wiele sytuacji szkolnych czy domowych może mieć swój nietypowy przebieg. Czym można się wesprzeć w tej niezwykle ważnej edukacji? Doris Brett stworzyła Opowiadania dla twojego dziecka ${ }^{40}$, a Gerlinde Ortner przygotowala Bajki na dobry $\operatorname{sen}^{41}$. Do obu zbiorów można spokojnie sięgnąć, by z ich pomocą odkryć wartość budowanego zaufania, zrozumienia i poczucia bezpieczeństwa między światami - tym dziecięcym i tym dorosłym.

\section{Śladami literatury}

Układ konstrukcyjny, charakterystyczny dla utworów terapeutycznych, znajdujemy u autorów tzw. wielkiej literatury. Oto kilka wybranych przykładów. Maria Konopnicka przeprowadzała swoją bohaterkę Marysię (której towarzyszył w wędrówce krasnoludek Podziomek) przez pola, ląki, las i góry, by wreszcie, dość nieoczekiwanie, pozwolić jej obudzić się w nowej roli w chacie Skrobka (O krasnoludkach i sierotce Ma$r \gamma s i)^{42}$. Marysia stała się bohaterką transformującą. Takie też zadanie Agacie, tytułowej postaci książki Jak mata Agata szła na koniec świata, powierzył autor, Janusz Domagalik ${ }^{43}$. Dziewczynka samowolnie jedzie do dziadka, ale równocześnie doświadcza różnych przygód w bezpiecznym otoczeniu, odkrywając ważne dla siebie przestrzenie i odpowiedzi na nurtujące ją pytania.

Podobne rozwiązania wprowadził C. S. Lewis w Opowieściach z Narnii. Pierwsza część cyklu - Lew, czarownica i stara szafa także zaprasza czytelnika do gry wyobraźni. Przygody czworga rodzeństwa po drugiej stronie szafy stają się projekcją zabawy w deszczowy, wakacyjny dzień, gdy w ponurym angielskim domu na wsi nie ma co robić. Tam również dokonuje się transformacja postaci, zwłaszcza Edmund doznaje przemiany, by zaakceptować wartości, na straży których stoi Aslan. Tę pozornie prostą rzeczywistość fantastycznego świata młodym objaśnia stary, poczciwy i mądry Profesor $^{44}$. W Matym Księciu rolę przewodnika, który jednocześnie poznaje siebie i świat, wziął na siebie tytułowy bohater ${ }^{45}$. Dorota Terakowska w Lustrze pana Grymsa czyni

\footnotetext{
40 Zob. D. Brett, Opowiadania dla twojego dziecka, tł. M. Majchrzak, Gdańsk 1998.

${ }^{41}$ Zob. G. Ortner, Bajki na dobry sen, tł. Z. Dalewski, Warszawa 1996.

${ }^{42}$ Zob. J. Cieślikowski, Baśń synkretyczna, op. cit., s. 38-71; M. Bolińska, Od narracji baśniowej po głosowy teatr Marii Konopnickiej (o retorycznych wartościach literackiej baśni), w: Teatr uymowy. Formy i przemiany retoryki użytkowej, red. J. Sztachelska, J. Maciejewski, E. Dąbrowicz, Białystok 2004, s. 351-370.

${ }^{43}$ Por. M. Bolińska, Historia o Agacie - bajka dziecięca?, w: eadem, Przez "Świat Młodych” do literatury. O prozie Janusza Domagalika, Kielce 2004.

44 Por. J. Ługowska, Funkcje motywów baśniouych w „Opowieściach z Narnii”, „Literatura Ludowa” 1989, nr 2, s. 3-13.

${ }^{45}$ Por. G. Leszczyński, Książka dla dziecka a myślenie symboliczne. Antoine de Saint-Exupéry, w: idem, Literatura i ksiqżka dziecięca, Warszawa 2003, s. 101-108.
} 
wzorem protagonistę - maga ${ }^{46}$, ale to niejako przypisane jest jego naturze. Główna postać opowiadania - Agata jest zaś typową kreacją bohatera transformującego.

\section{Wartości opowieści}

Wskazując na wartości opowiadań z akcentem ludycznym, należy pamiętać, że między światem realnym i iluzyjnym, w autonomicznej przestrzeni dziecięcej kultury znajdują się zabawki, których przedmiotowość i poetyckość, czyli forma nadbudowana, istnieje ontycznie. W tym „drugim świecie” zabawa staje się płaszczyzną kontaktu i porozumienia $\mathrm{z}$ dzieckiem.

W tym sensie — podkreśla Alicja Baluch - literatura jest także formą zabawy poprzez różne gry językowe, struktury obrazowe i fabularne, a jej osią konstrukcyjną może być bohater literacki ${ }^{47}$.

Dziecko z reguły poznaje najpierw zwierzątka z książeczek obrazkowych, które w swej konstrukcji zbliżone są do wzorów ludzkich, następnie zaczyna dokonywać antropomorfizacji, traktując bohaterów jak rówieśników, wprowadza podział na ludzi „małych i dużych”, dalej zaprasza do swego świata i języka postaci baśniowe - królewny, rycerzy, krasnoludki, plastusie ${ }^{48}$ (łączy je wspólna cecha - są dużo mniejsze od dziecka). Dlatego pierwszym i najszybciej rozpoznawalnym przez dziecko obrazem postaci literackiej jest obraz graficzny, znany z ilustracji; potem postaci ze świata rysunków przez identyfikację stopniowo wchodzą w życie dziec$\mathrm{ka}$, by wreszcie dotrzeć do etapu ocen, porównań, zestawień, które będą budować związki z literacką tradycją.

Utwory celowo kierowane do młodego odbiorcy wykorzystują zarówno dziecięcy typ wyobraźni, dziecięcy język i formę artystycznego przekazu, jaką jest towarzysząca słowu ilustracja, jak też mogą być traktowane jako sposób na uaktywnianie umysłu, inteligencji oraz pomysłowości dzieci w układaniu i wyobrażaniu sobie niesamowitych historii. Pewne jest, że opowieści mogą być i „do oka czy ucha”, „przy kominku”, „do łóżeczka”, „do snu”, „na dobranoc”49, ale ich urody i funkcji nie zastąpi nawet najciekawsza audycja w telewizji.

46 Zob. M. Bolińska, Powieść to tė labirynt, czyli Dorota Terakouska o sobie i swoich ksiązkach, w: Wokót literatury i kultury. Prace dedykowane Profesorowi Janoui Pactawskiemu w roku Jubileuszu, red. J. Detka, M. Kątny, S. Rogala, Kielce 2005, s. 25-35.

${ }^{47}$ A. Baluch, Bohater literacki w funkcji pośrednika, w: eadem, Dziecko i świat przedstawiony..., op. cit., s. 71 .

${ }^{48}$ Zob. ibidem, s. 74-82; por. także eadem, Ceremonie literackie, a więc obrazy, zabauy i wzorce $w$ utworach dla dzieci, Kraków 1996.

${ }^{49}$ Por. J. Cieślikowski, Sposoby istnienia bajki dziecięcej, op. cit., s. 198-238. 
Natomiast rodzice i/lub dziadkowie wcale dobrze mogą sprawdzić się w tej materii. Wspólne czytanie, opowiadanie, tworzenie może być podstawą nierozerwalnej więzi, ale i twórczą zabawą w formowanie się, która przeradzając się w skladnik rozwojowo-wychowawczy, wyda stokrotny plon. Zwłaszcza gdy opowiadacz lub twórca uwzględni wymiar terapeutyczny i artystyczny. Zrozumiałe wydaje się być więc zaangażowanie wielu osób w kampanię na rzecz kontaktu z książką — Cata Polska czyta dzieciom. Można dodać — i dzieciom opowiada oraz pozwala opowiadać im samym. 